\title{
Food for thought
}

\author{
By Helen L. Gater
}

Library Director

Arizona State University West

\section{Do food bans really serve their purpose?}

Why is reading such hungry work? When I push back in my recliner with a good novel or the latest management book, it isn't long before I need something more substantial than the cup of coffee at my elbow-something I can get my teeth into. In dorm rooms across every campus, popcorn, stale pizza, candy wrappers, and drink containers mark the progress of the learning process. In the union students are reading intently, not with pencils poised, but french fries dredged in ketchup. Everywhere you look people devour calories along with words as though they were as inseparable as peanut butter and jelly. Everywhere, that is, except the library!

I have two problems with policies banning food and drink from the library. First, I believe that policies should serve the purpose for which they are established. What is the purpose of this ban? Is it to protect the books? Not if we check them out! Take a look at the books in my lap, the dorm rooms, and the student union. Many of them will have call number labels.

Dowe want to keep out food particles that attract vermin? Those nasty crumbs are already hiding between the pages of books that come back to the library. Besides, open the desk drawer of any staff member and you will find a supply of munchies. A mouse took up residence in the food vending machine in our library staff room. It ventured into a few desk drawers to sample the goodies but never got desperate enough to attack books. Exterminators can handle vermin and they need to make a living.

Do we want to protect the carpet? Our worst carpet damage has been from a flood and from spilled beverages that we served at meetings! If the problem is the trash that is left behind, we might consider installing large, preferably covered and attractive trash containers. A student organization might even be willing to finance the purchase and encourage their use.

The other problem I have with the food and drink ban is that it is not very customer oriented. The students who live on campus have a number of options, but the adult part-time students who come directly to campus from work need all the breaks

\section{A sandwich is one thing, but spaghetti is another.}

they can get. So why make them check out a stack of books and carry them out of the library before they can munch their sandwich?

Yes, people do get carried away. A sandwich is one thing, but spaghetti is another. We can't very well have a list of permissible or banned foods, but what is wrong with judgment and selective enforcement? We're already selective by omission: no library has the staff to patrol the stack and study areas looking for violators, so anyone who smuggles in munchables and munches them discreetly goes unnoticed. Let's get righteous about gross violators and about enforcement around the electronics and any rare materials - the crown jewels of the library. Let's also get righteous about savory smells wafting under the noses of those who didn't pack their lunch. Then, let's allow those who use good judgment to read and dine in peace. A peaceful mind is good for digestion of both words and food. 